\title{
Utilising SATA in Measuring Students' Understanding of Financial Statements: A Survey among Non-Accounting Students
}

\author{
Adriana Shamsudin ${ }^{1 凶}$, Nur Farahah Mohd Pauzi ${ }^{2}$, Mohd Syazwan Karim ${ }^{3}$, \\ Nurfarahin Roslan ${ }^{4}$ and Khairiah Ahmad ${ }^{5}$
}

1,2,3,4,5 Universiti Teknologi Mara (UiTM) Cawangan Melaka, Kampus Jasin, 77300 Merlimau, Melaka, Malaysia

DOI: http://dx.doi.org/10.15294/jda.v12i1.24811

Submitted: May $5^{\text {th }}, 2019$ Revised: September $15^{\text {th }}, 2019$ Accepted: January $20^{\text {th }}, 2020$ Published: March $31^{\text {th }}, 2020$

\begin{abstract}
Accounting is perceived as a complicated process due to its technical difficulties. However, accounting knowledge is undeniable essential to complete a business plan. The 'Simplified Accounting Template for Apprentice' (SATA) is developed to facilitate students especially non-accounting students who have very little accounting knowledge in preparing proforma financial statements at the financial section in the business plan. SATA act as integral part of technology used in accounting education to improve students' understanding on accounting and help them to complete the business plan. The objective of this paper is to access the level of students' understanding on accounting with the introduction of SATA in teaching and learning which finally can assist them to prepare financial statements. A hands-on workshop was conducted by accounting lecturers in UiTM Malacca Branch Jasin Campus on SATA to assist the students in completing the business plan for financial section. A questionnaire was given at the end of the workshop to the students to gather their feedback related on SATA and give their perceptions using SATA in preparing financial statements. This study found that more than $80 \%$ respondents admitted that SATA improved their understanding on accounting terms such as terms of non-current assets, non-current liabilities, sales, purchases, $85 \%$ agreed that SATA took lesser time to prepare financial statements, $90 \%$ found that SATA was very easy to use as compared to manually prepared the financial statements and facilitates in analyzing financial performance and $91 \%$ agreed that SATA really help them in completing their business plan particularly in financial section. On overall most of respondents admitted that SATA increase their understanding in preparing financial statements. This study also revealed that most of the respondents understand the component of Statement of Profit or Loss and Statement of Financial Position embedded in SATA.
\end{abstract}

Keywords: accounting technology, accounting education, accounting template, students' understanding, financial statements, non-accounting students

How to cite (APA 6th Style)

Shamsudin, A., Mohd Pauzi, N., Karim, M., Roslan, N., \& Ahmad, K. (2020). Utilising SATA in Measuring Students' Understanding of Financial Statements: A Survey among Non-Accounting Students. Jurnal Dinamika Akuntansi, 12(1), 24-33. doi:https://doi.org/10.15294/jda.v12i1.24811

author $(\square)$

E-mail: adriana416@uitm.edu.my 


\section{INTRODUCTION}

To date, the government has launched a programme called Protégé that has been rebranded from Skim Latihan 1Malaysia (SL1M) to focus on entrepreneurship training with the ultimate aim to produce more entrepreneurs or job creators (The Star Online, 2019). In line with the government continuous efforts, Universiti Teknologi MARA (UiTM) also has came out with strategic collaboration as part of its holistic approach in building entrepreneurship spirit among the students towards producing holistic graduates (Bernama, 2018). Hence, UiTM has made an entrepreneurship subject, ENT 300: Fundamental of Entrepreneurship as a compulsory subject for all the undergraduate students at diploma level. One of the requirement for this subject is the students need to prepare a business plan. Therefore, accounting knowledge is undeniable essential to complete the business plan for the financial section. Besides, accounting literacy is a key role in the success and failure of the business as it deals with the effectiveness of planning and managing the financial matters in order to identify cash flow, cost of production, assets and liabilities (Umeji \& Obi, 2014).

Nevertheless, accounting is perceived as a complicated process due to its technical difficulties. Even though accounting subject has been introduced earlier than entrepreneurship subject but the students still struggling with the preparation of business plan due to a number of non-accounting students did not perform well in the accounting courses (Illias et al. 2009). A study done by Muda et al. (2013) revealed that one of the major contributing factors of failure for accounting subject is the subject being a non-preferred course. Currently, the students prepare their business plan with the aid of teaching material from their lecturers and available template either from their lecturers as well or available online for free. However, the ready-made templates that are currently available do not fulfil the requirement of business plan that the students need to prepare especially at the financial section. Mostly, the ready-made template available online are focusing more on small business owners (Monster, 2020), (ABSS Accounting Software, 2020), (COUNT, 2020). There was also ready-made template specifically designed from previous researchers for students (Wahab, 2017). However, the designed template is not simple and quite difficult for non-accounting students to understand. This definitely lead the students to confusion and ultimately students complete the financial section with try and error and without in-depth understanding of what they do.

The simplified accounting template is developed to facilitate students especially nonaccounting students who have very little accounting knowledge in preparing proforma financial statements at the financial section in the business plan. Indeed, the template was designed specifically to create proforma financial statements based on the estimated information on sales, purchase, expenses, non-current assets, non-current liabilities, drawings and other revenues. Finally, the template will automatically generate four types of statements which include Proforma Production Account, Proforma Cash Flow Statement, Proforma Statement of Profit or Loss and Proforma Statement of Financial Position. Besides, financial statement analysis using basic financial ratio such as liquidity ratio, efficiency ratio and profitability ratio will be automatically calculated. The comprehensive understanding on each of the principles underlying the financial statements prepared would be useful for the students in applying the knowledge when seeking the funding from agency such as Tekun Nasional in order to start their business ventures. A lot of financing schemes available for graduates to grab among others are Bumiputera Young Professional Programme, Graduate Entrepreneur Development Programme, Tekun Business Financing Scheme, Young Agropreneur Programme and Tekun Business Financing Scheme (www.tekun.gov.my).

Therefore, this study focus on the extent of students' understanding on accounting with the introduction of simplified accounting template in teaching and learning which finally can assist them to prepare the business plan. The remainder of the paper is arranged as follows. The next section reviews the relevant literatures and then follows with the description of research method used in this study. The subsequent section discusses the result of the study and the final section 
highlights on the implication and limitation of the study as well as suggestion for future research. Industrial Revolution 4.0 (IR 4.0) transforms the landscape of new educational technology and bringing the idea of digital and online education (Aida Aryani \& Norhayati, 2018). Professional agencies give special importance for accounting educators to consolidate more technologies into classroom (Holmes \& Rasmussen, 2018). The physical look of university classroom is merely the same compared to the last ten years but the classroom interaction has been completely revolutionized (Wynn, 2013). Students are exposed to an electronic version that connects them with millions of application, software, wide range of social media and internet options (Holmes \& Rasmussen, 2018). Recently, the newest technology like media social starts to evolve and has a great potential and contribution in accounting and educational settings. The educators and students are communicating effectively through virtual world such as WhatsApp, Facebook Messenger and some through Twitter. However, in order to make an effective learning environment, the educators should identify the best technology to be incorporated in the classroom to ensure students are familiar and proficient in using it (Wynn, 2013). Based on prior studies, (Durak et al., 2017) revealed that online education is interrupted when the internet network facility provided by the university is poor. Therefore, in order to support this online education, the universities need to provide $\mathrm{Wi}$-Fi and strengthen the internet coverage in classroom to allow the educators and students access to the internet (Halaweh, 2017).

The inclusion of technology in classroom provides good impact to the students' interactive learning process as a whole. Visual illustration applied in classroom helps the students' brain to capture and grasp information easier (Wynn, 2013). Based from (Jackson, 2013), he discovered that mobile phones are viewed as mostly distraction tools whereas laptop provides helpful learning assistance. Most of the students justify that the mobile technology is used by the students to cheat. However, (Durak et al., 2017) found that when the educators using interactive board in making presentation in class, there is a positive effect on students' involvement. A study conducted by (Halaweh, 2017) also support that the usage of smartphones and laptop in class allows the students to search for knowledge through You Tube videos, English dictionary application, calculator through mobile version Excel and added link of videos for presentation purposes.

In accounting education, technologies have been traditionally embedded in accounting classes through the application of database, spreadsheets and various accounting software (Holmes \& Rasmussen, 2018). A study done by (Ahadiat, 2008) found that accounting information system subject had a greater need in data analysis, presentation software and spreadsheets for students assignment. Substantial effort should be done by accounting industry to emphasize the importance of IT in accounting related jobs (Pan \& Seow, 2016). (Holmes \& Rasmussen, 2018) found that students with non-accounting background normally struggle in learning accounting. Thus, it is recommended to incorporate more technology based learning experiences into accounting courses.

\section{METHODS}

\section{Sample and Data Collection}

Respondents were selected from fifth semester students of Diploma in Plantation Management (AT110) in Universiti Teknologi Mara (UiTM) Melaka Branch, Jasin Campus whose taking subject 'ENT 300: Fundamental of Entrepreneurship'. A 'Financial Planning for Young Agropreneurs' workshop was conducted on 20th October 2018 by accounting lecturers to deliver and explain step-by-step process to handle SATA. This hands-on workshop is very important to convey relevant information required before using SATA. The students so as the lecturers should have clear understanding of technology used in class (Wynn, 2013). Each group of student was assigned to establish a business and make business proposal which known as 'business plan. This business plan constitutes four major sections which are (1)Operational, (2)Administrative, (3) Marketing and (4)Financial information. SATA helps the students to prepare on financial part of the business plan. 
They were distributed with a set of questionnaire and data were collected during the workshop. A total of 105 students responded with approximately 5 minutes to complete the questionnaire. This study is unique as it considers the students' performance in a subject that is not the main discipline of the students. This study uses a survey to obtain data on the effect of introducing simplified accounting template among non-accounting students. According to Cooper and Schindler (2001), the survey method would be the best approach in gaining opinions or perceptions. By distributing questionnaires, respondents' perceptions and opinions were obtained easily and in less time.

\section{Development of SATA}

In this research, the technology adapted in teaching and learning was centrally focusing on SATA. SATA is an accounting automatic template developed to facilitate students who have very little accounting knowledge in preparing financial statements. The template was developed by three (3) accounting lecturers that have teaching experience of more than seven (7) years and two (2) senior lecturers that have more than fifteen (15) years of teaching experience. SATA was developed in line with the entrepreneurship subject syllabus and get consistent advice from three (3) business lecturers. This template mainly focusing on those whom needs to prepare proforma financial statements for their business plan. This template is expected to provide assistance especially for those students who are taking ENT300 (entrepreneurship) subject. In addition, the accounting software that available online often targeted big companies and those companies that already started their operation and have actual transaction for their business.

SATA template consisted of three main sections which are Section A: Recording transactions, Section B: Financial Statements and Section C: Analysis. A summary of the items under each section are listed in Table 1.

Table 1. Summary of SATA Items

\begin{aligned} & \hline Section A: Recording Transactions (eight main components in SATA) \\ & 1. To Record Sales \\ & 2. To Record Purchase of Raw Materials \\ & 3. To Record Payment of Salaries \\ & 4. To Record Expenses \\ & 5. To Record Non-Current Assets \\ & 6. To Record Non-Current Liabilities \\ & 7. To Record Drawings \\ & 8. Other Parts \end{aligned}

Section B: Financial Statements (automatically generated by SATA)

1. Pro-forma Production Account

2. Pro-forma Cash Flow Statement

3. Pro-forma Statement of Profit or Loss

4. Pro-forma Statement of Financial Position

Section C: Financial Statements Analysis (automatically generated by SATA)

1. Liquidity Ratio

2. Efficiency Ratio

3. Profitability Ratio

User needs to fill up eight main components in SATA template which includes 'To Record Sales', 'To Record Purchase of Raw Materials', 'To Record Payment for Salaries', 'To Record Expenses', 'To Record Non-Current Assets', 'To Record Non-Current Liabilities', 'To Record Drawings' and 'Other Parts'. After user fill up all the details in the eight main components of SATA, the template will automatically generate four types of financial stataments which include Proforma Production Account, Proforma Cash Flow Statement, Proforma Statement of Profit or 
Loss, Proforma Statement of Financial Position and Financial Statement Analysis. SATA helps the students to generate financial statements information for three years period.

\section{Development of Questionnaires}

A set of questionnaire was used in this study as data collection instrument. The design of the questionnaire covered three sections. Section A requires respondents' demographic information, while Section B requires respondents' feedback on the Simplified Accounting Template for Apprentice (SATA) which comprises of 27 significant questions related to the SATA component. In addition, Likert scale is used in Section $\mathrm{C}$ for respondents' perceptions using SATA in preparing financial statements. A summary of questions under each section are listed in Table 2.

Table 2. Summary of Questions

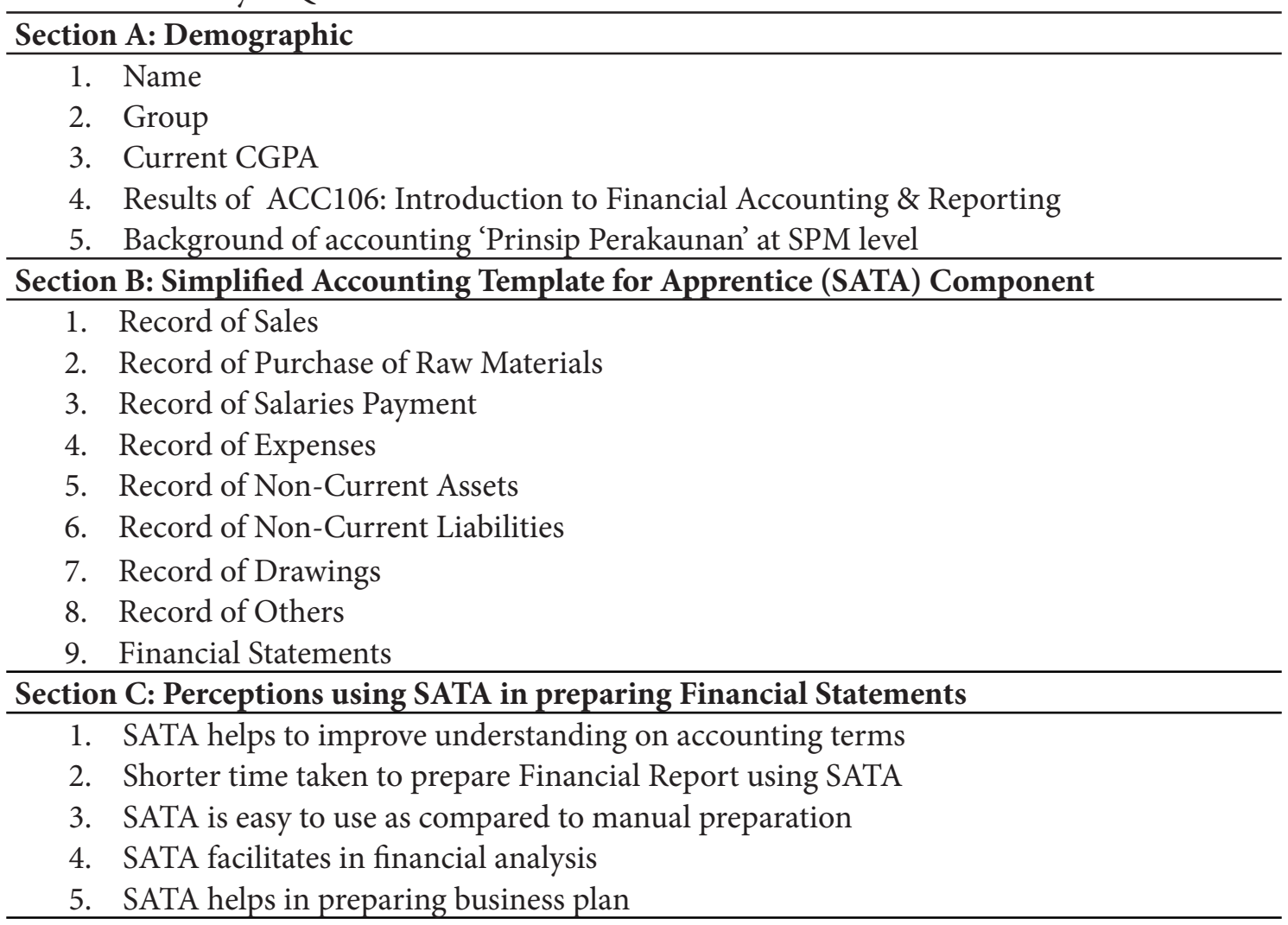

For the purpose of analysing the data, the Statistical Package for Social Science (SPSS) software was used. The statistical techniques adopted were descriptive statistics (frequency tabulation).

\section{RESULTS AND DISCUSSION}

This study distributed 105 survey questionnaires to selected students in part five (5) of Diploma in Agriculture and Technology Management (AT110) UiTM Melaka Branch Jasin who attended 'Financial Planning for Young Agropreneurs' workshop. All responses were received or 100 percent response rate.

\section{Section A: Demographic}

Table 1. below summarizes Section A of the questionnaire which is on demographic information includes current CGPA, result of the subject ACC106 (Introduction to Financial Accounting and Reporting), number of students taken 'Prinsip Perakaunan' during secondary school and the result of subject 'Prinsip Perakaunan'of the respondents. 
Table 3: Respondents' Profile

\begin{tabular}{|c|c|c|c|}
\hline Detail & Particular & Total & Percentage \\
\hline \multirow{5}{*}{$\begin{array}{l}\text { Current CGPA } \\
\text { (Cumulative Grade Point Average) }\end{array}$} & $3.50-4.00$ & 30 & $28.6 \%$ \\
\hline & $3.00-3.49$ & 43 & $41 \%$ \\
\hline & $2.50-2.99$ & 27 & $25.7 \%$ \\
\hline & $2.00-2.49$ & 5 & $4.8 \%$ \\
\hline & Less than 2.00 & 0 & $0 \%$ \\
\hline \multirow{4}{*}{$\begin{array}{l}\text { Result ACC106 } \\
\text { (Introduction to Financial } \\
\text { Accounting and Reporting) }\end{array}$} & $\mathrm{A}-/ \mathrm{A} / \mathrm{A}+$ (pass) & 65 & $61.9 \%$ \\
\hline & B-/ B/ B+ (pass) & 24 & $22.9 \%$ \\
\hline & $\mathrm{C} / \mathrm{C}+$ (pass) & 16 & $15.2 \%$ \\
\hline & C- and below (failed) & 0 & $0 \%$ \\
\hline \multirow{2}{*}{$\begin{array}{l}\text { Number of students taken 'Prinsip } \\
\text { Perakaunan' subject during SPM } \\
\text { Level. }\end{array}$} & Yes & 25 & $23.8 \%$ \\
\hline & No & 80 & $76.2 \%$ \\
\hline \multirow{3}{*}{$\begin{array}{l}\text { Result of subject Prinsip Perakaunan } \\
\text { during SPM Level (for student answer } \\
\text { Yes) }\end{array}$} & Credit (Grade C and above) & 24 & $96 \%$ \\
\hline & Not credit (Grade D \& E) & 1 & $4 \%$ \\
\hline & Failed (Grade G) & 0 & $0 \%$ \\
\hline
\end{tabular}

The respondents were selected in random from those students attending the workshop. The students coming from different background range of CGPA. The majority of respondents which is $69.6 \%$ are having CGPA of 3.00 and above. ACC106 was an introductory accounting subject for non-accounting students offered during their semester three (3). The basic knowledge gained from the subject is beneficial and very useful to be applied when they want to use SATA. SATA requires the user to have at least basic accounting knowledge to handle SATA. From the data collected, $61.9 \%$ of the respondents got 'A' results in ACC106 subject and none of the respondents failed the subject which indicates that the students are having sufficient basic accounting knowledge before handling SATA. Even though 76.2\% do not have basic accounting knowledge during their secondary school, they can still master the SATA template as they have been equipped by sufficient basic accounting knowledge when they took ACC106 subjects in university.

\section{Section B: Simplified Accounting Template for Apprentice (SATA) Component}

This study revealed respondents' level of understanding to component in Statement of Profit or Loss and Statement of Financial Position after they use SATA in preparing financial statements and this evidences are shown in Figure 1 and 2.

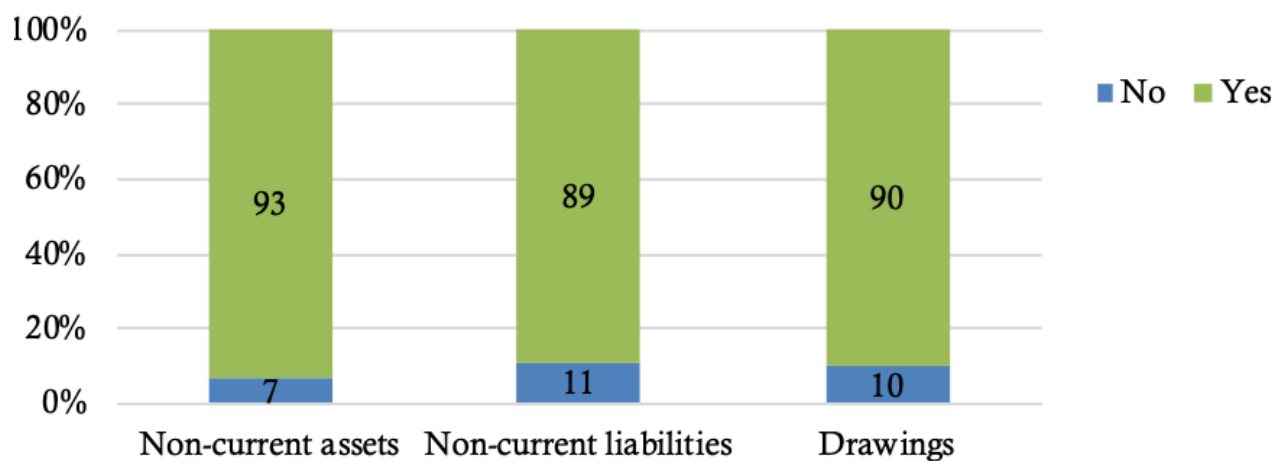

Figure 1. Responses of understanding to component in Statement of Financial Position after use SATA. 
Figure 1 shows the responses on components in Statement of Financial Position after they use SATA. Most of them have clear understanding with components in Statement of Financial Position for instance non-current assets, non-current liabilities and drawings. $93 \%$ of respondents understand the non-current asset items. During the workshop, for example, the students establish a food manufacturer company such as 'Keropok Lekor Factory', the students manage to identify the non-current assets related with the business such as kitchen utensils, kitchen equipment and mixing and boiling machines. The students also were able to identify any new acquisition of assets or any disposal of assets during the first three years. $89 \%$ of respondents also manage to understand and categorized correctly the items under liabilities. They managed to segregate short and long term loan under the correct categories either as current or non-current liabilities. They also manage to identify additional loan and repayment every year. $90 \%$ was found to have clear understanding on drawings as the students manage to differentiate between expenses related to business and expenses incurred by owner for personal use. The students manage to identify correctly the classification of the items as two-way communication and interaction during the workshop. In order to ensure the technology is successfully implemented, students and teachers need to be fully involved in the whole assistive technology process (Karlsson, Johnston, \& Barker, 2017).

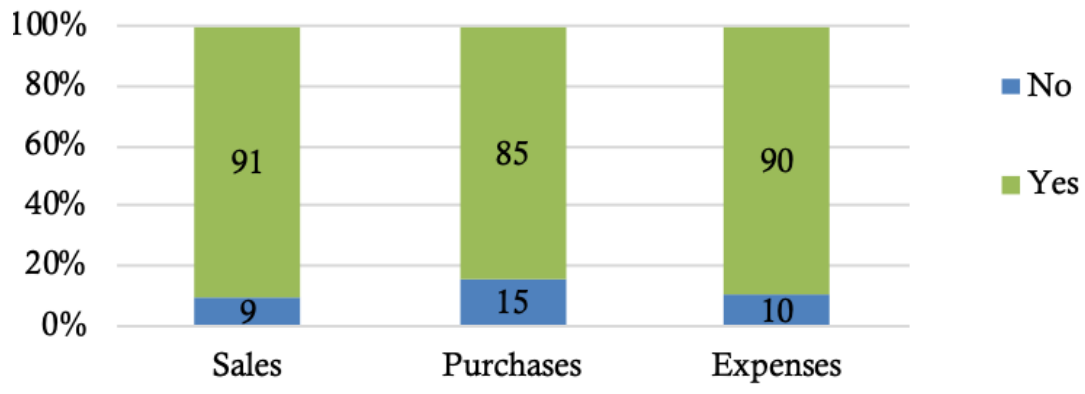

Figure 2. Responses of understanding to component in Statement of Profit or Loss after use SATA.

Figure 2 shows the responses on components in Statement of Profit or Loss after they use SATA. The results revealed that $91 \%$ know exactly what should be recorded under sales. For example, if the students establish a trading company like bookshop, the students were able to identify their main source of revenue is coming from selling of books and stationeries. They also noticed that information in sales will give significant contribution as main revenue. $85 \%$ of the respondents properly classified the purchasing of raw materials under purchase section in SATA. For example, if the students created a burger kiosk stall, the purchase of raw materials should be frozen meat burger, bread, tomatoes, cucumber, onions, and eggs. The students also aware that the purchase of raw materials are classified under expenses and should be recorded in manufacturing account in order to calculate the total production cost. This SATA template segregates the information of expenses into two categories which are salaries expenses payment and other expenses payment. The two expenses will give effect to manufacturing account and statement of profit or loss. $90 \%$ of the respondents understand the right information to be filled up under expenses section. Most of them also were able to differentiate expenses incurred in administrative, marketing and operational activities.

These results show level of students' understandings on accounting are increase after they use SATA in preparing financial statements. By having good basic knowledge in accounting through ACC106 subject, the students were able to understand correctly the components in SATA. Therefore, this study revealed importance of SATA as integral part of technology used in accounting education to improve students' understanding on accounting and help them to complete the business plan. 


\section{Section C: Students' perceptions using SATA in preparing Financial Statements}

Next, this study assessed on student's perception of using SATA in preparing proforma financial statements which includes proforma production account, proforma cash flow statements, proforma statement of profit or loss, proforma statement of financial position and financial statement analysis.

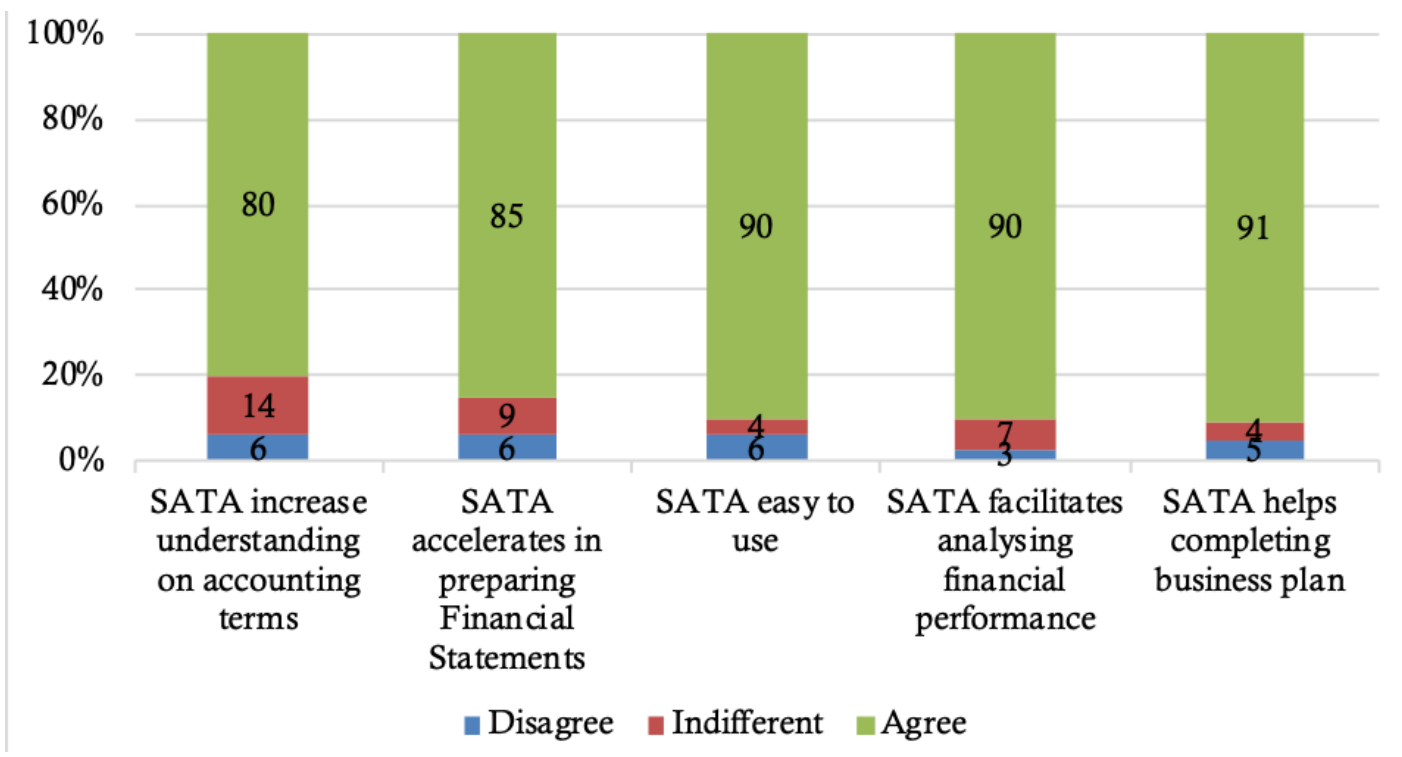

Figure 3. Respondents' General Overview on SATA

Notes: Students responded to a Likert-type scale of 1-5 (1- strongly disagree; 2 - disagree; 3indifferent; 4- agree; 5- strongly agree) in this figure, the two responses, i.e. strongly disagree and disagree are classified as "disagree" and agree and strongly agree as "agree"

Figure 3 shows respondents' general overview on SATA. The results found that $80 \%$ of the respondents admitted that SATA improved their understanding on accounting terms such as terms of non-current assets, non-current liabilities, drawings, sales, purchases and expenses. Students are able to recognize appropriate accounting terms and apply the usage of the terms in their business plan under financial sections. SATA guides the students to insert only important information in their business plan to generate financial statements.

$85 \%$ of respondents feel that SATA accelerates the student time in preparing financial statement. Once the students fill up important information under Section A Table 1, SATA template will automatically generate financial statements for the students. Students do not need to memorize the required format and calculate manually. It only took two to three hours to fill up the information and finally complete the financial part of business plan. If the students want to prepare it manually, normally it would take about two to three days to produce the financial statements. The usage of SATA is really beneficial and requires lesser time to produce the desired report. $90 \%$ of the respondents admitted SATA was very easy to use as compared to manually prepared financial statements. This template only requires the students to fill up eight components of SATA which is very minimal recording compared to overall accounting recording process. Even though SATA is undeniable easy to use, the trainer of SATA should be well verse on the overall template of SATA so that they can convey accurate information to the user of SATA. It is in line with study done by (Durak et al., 2017) who emphasize that the teachers must have an adequate training and literate enough to use technology in classroom.

Around $90 \%$ of respondents believed that SATA facilitates them in analyzing financial performance. This template provides access to financial statements analysis. The analysis covered three aspect of analysis which are (i) liquidity (current ratio and quick ratio), (ii) efficiency (average 
collection period) and (iii) profitability (gross profit margin and net profit margin). SATA also generate automatically the graphs for each ratios for the user to see the pattern trend analysis over the period of three years. $91 \%$ per cent realized that SATA really help them in completing their business plan particularly in financial section. On overall, most of respondents admitted that SATA increase understanding in preparing financial statements.

\section{CONCLUSIONS}

This study focuses on the extent of students' understanding on accounting with the introduction of simplified accounting template in teaching and learning which finally can assist them to prepare the business plan. This study revealed that respondents' level of understanding to component in Statement of Profit or Loss and Statement of Financial Position after they use SATA is very high. Most of them have clear understanding with components such as non-current assets, non-current liabilities, drawings, sales, purchase of raw materials and expenses. SATA helps the students to understand the information required to be presented in business plan under financial sections. This study also revealed that SATA increase understanding on accounting terms, took lesser time to prepare financial statements, very easy to use as compared to manually prepared financial statements, facilitates in analyzing financial performance and really helpful in completing business plan particularly in financial section. Therefore, SATA which act as integral part of technology used in accounting education improve students' understanding on accounting and help them to complete the business plan.

\section{Limitations of Study}

The method used in this study is only based on survey questionnaires. Therefore, it is recommended for future research to definitely incorporate a mixed-methods approach, in that both the descriptive and qualitative approach such as interviews to gain more reliable input from the students.

\section{Acknowledgements}

Our sincere thanks to Universiti Teknologi Mara (UiTM), Malacca Branch Campus, Malaysia who gave some funding contribution for our research.

\section{REFERENCES}

ABSS Accounting Software. (2020). Retrieved from https://www.abssasia.com/freetrial?gclid=EAIaIQobChMIi9nq_Y_T6gIV0XwrCh3hmA_6EAAYASAAEgJj-_D_BwE

Ahadiat, N. (2008). Technologies Used in Accounting Education: A Study of Frequency of Use Among Faculty. Journal of Education for Business, 83(3), 123-134.

Aida Aryani, S., \& Norhayati, H. (2018). Industrial Revolution 4.0 and Education. Management Academic Research Society (HRMARS), 8(9), 314-319.

Bernama (2018). Richiamo Coffee to have 10 outlets by year-end. October 2018. Retrieved from http:// www.bernama.com/en/news.php?id=1657113

Cooper, D.R., \& Schindler, P.S. (2001). Business Research Methods (8th ed.). Sydney: McGraw-Hill Irwin.

COUNT, A. A. (2020). AC AUTO COUNT. Retrieved from https://www.autocountsoft.com/freetrial. html?gclid=EAIaIQobChMIi9nq_Y_T6gIV0XwrCh3hmA_6EAAYBCAAEgKMgfD _ BwE\#accounting

Durak, H. Y., Saritepeci, M., Üniversitesi, B., Fakültesi, E., Türkiye, B., Bakanlığı, M. E., \& Türkiye, A. (2017). Investigating the Effect of Technology Use in Education on Classroom Management within the Scope of the FATiH Project FATiH Projesi Kapsamında Eğitimde Teknoloji Kullanımının Sınıf Yönetimi Üzerine Etkilerinin İncelenmesi. Çukurova Üniversitesi Eğitim Fakültesi Dergisi, 46(2), 441-457.

Halaweh, M. (2017). Using Mobile Technology in the Classroom: A Reflection Based on Teaching Experience in UAE. TechTrends, 61(3), 218-222.

Holmes, A. F., \& Rasmussen, S. J. (2018). Using Pinterest to stimulate student engagement, interest, and learning in managerial accounting courses. Journal of Accounting Education, 43(November 2017), 43-56.

Illias, I., Yasoa, M. R., Abd Rahman, R. \& Abd Razak, M. Z. (2013). The Study of Students' Perception 
Towards Principle of Accounting (pa): A Survey Among Business Students, IBEJ, 2(1).

Jackson, L. D. (2013). Is mobile technology in the classroom a helpful tool or a distraction?: A report of university students' attitudes, usage practices, and suggestions for policies. International Journal of Technology, Knowledge and Society, 8(5), 129-140.

Karlsson, P., Johnston, C., \& Barker, K. (2017). Stakeholders' views of the introduction of assistive technology in the classroom: How family-centred is Australian practice for students with cerebral palsy? Child: Care, Health and Development, 43(4), 598-607.

Monster, T. (2020). 42 ACCOUNTANT WEBSITE TEMPLATES. Retrieved from https://www. templatemonster.com/category/accounting-website-website-templates/

Muda, S., Hussin, A. H., Johari, H., Mohamed Sapari, Jamil. \& Jamil, N. (2009). The Key Contributing Factors of Non-Accounting Students' Failure in the Introduction to Financial Accounting Course, Procedia - Social Behavioral Sciences, 90, 712-719.

Pan, G., \& Seow, P. S. (2016). Preparing accounting graduates for digital revolution: A critical review of information technology competencies and skills development. Journal of Education for Business, 91(3), 166-175.

The Star Online (2019). Protégé rolls out job traning events. April 2019. Retrieved from https://www.thestar. com.my/news/nation/2019/04/08/protege-rolls-out-job-training-events/

Umeji, A. U. \& Obi, C. A. (2014). Cost Accounting Skills Needs of Small Business Operators, American Journal of Industrial and Business Management, 4(5), 246-257.

Wahab, I. A. (2017). Fine Planner.

Wynn, M. F. (2013). Student Perceptions of Technology in the Classroom: a Faculty and Student Collaboration. Researcher: An Interdisciplinary Journal, 26(3), 21-33. Retrieved from https://reddog. rmu.edu/login?url=http://search.ebscohost.com/login.aspx?direct=true\&db=a9h\&AN=94391331 \&site $=$ ehost-live\&scope $=$ site 